Gut, 1966, 7, 344

\title{
Comparison of the rates of gastric acid secretion in man after ingestion of food and after maximal stimulation with histamine
}

\author{
S. J. RUNE \\ From the Department of Clinical Physiology and Surgical Department A, Bispebjerg \\ Hospital, Copenhagen, and the Institute of Experimental Research in Surgery, \\ University of Copenhagen, Denmark
}

EDITORIAL SYNOPSIS The question posed is, 'How intense is gastric acid secretion when we eat normal food'? The answer from these studies suggests that the rate of acid secretion is approximately the same as that stimulated maximally by histamine.

The mode of stimulating the parietal cells during gastric function tests in man has changed many times since the introduction of the stomach tube first made this kind of investigation possible.

For many years 'the fractional test meal' (Ewald) was used, but the response was often too arbitrary, presumably because the stimulation was inadequate. Other test meals composed of liquid food, with a higher protein content than the Ewald meal, were subsequently introduced. This group of tests gives good information on the acidity occurring in the stomach, but quantitative determination of the acid secretion is not possible owing to the lack of information on the amount and composition of the juice passing through the pylorus.

In contrast, the widely used augmented histamine test of Kay (1953) today makes it possible to measure the gastric secretory capacity in milliequivalents $\mathrm{H}^{+}$ secreted per hour. Its greatest theoretical limitation is that it gives information only on the performance of the parietal cell mass under the specific test situation and leaves the important question open, Does the maximal histamine stimulation represent a completely unphysiological stress, provoking an excessive acid output which bears little or no relation to the acid secretion following ingestion of food? In other words, How intense is the gastric acid secretion when we eat normal food?

In order to answer this question a technique was developed for measuring the gastric secretion of acid without involving aspiration of the stomach contents (Rune, 1965). It is based on the concept that for each equivalent amount of hydrochloric acid secreted into the stomach lumen an equivalent acid deficit will arise in the rest of the body. Calculating this acid deficit from measurements of the base content in multiple arterial blood samples allows estimation of the gastric acid secretion in man during the augmented histamine test.

This paper presents the results obtained by applying the same method during digestion of normal solid food in human subjects.

\section{METHODS}

The secretion of hydrogen ions from the gastric mucosa means to the body an equivalent acid deficit, which in the following will be called a 'base accumulation'. Knowing the volume in which the base excess is distributed, it is possible to calculate the rate of base accumulation from measurements of the rise in base concentration in arterial blood.

DETERMINATION OF THE BASE EXCESS Through an indwelling needle in the femoral artery blood samples were obtained at intervals of 10 to 20 minutes. Immediately after drawing the blood, $\mathrm{PCO}_{2}$ and $\mathrm{pH}$ were measured in duplicate, using a Severinghaus $\mathrm{PCO}_{2}$ electrode (E.I.L.) and an Astrup capillary glass $p \mathrm{H}$ electrode (Radiometer, Copenhagen). The 'base excess' concentration in milliequivalents per litre of blood was read from the nomogram constructed by Siggaard-Andersen (1962) after the $\mathrm{CO}_{2}$-equilibration line was determined, taking two successive blood samples, one during hypoventilation and one during hyperventilation. The base excess (BE) value expresses the amount in milliequivalents per litre of blood of non-volatile base added to the blood, taking the blood of the subject with normalized $\mathrm{PCO}_{2}$ and $p \mathrm{H}$ $(40.0 \mathrm{~mm}$. and 7.400 ) as zero (Astrup, Jørgensen, Siggaard-Andersen, and Engel, 1960).

EXCRETION OF ACID OR BASE IN URINE Urine was collected through a bladder catheter during all investigations. The 
amount of acid or base excreted was measured by titration to $p \mathrm{H} 7.4$ with $\mathrm{N} / 10 \mathrm{NaOH}$ after boiling with strong acid and addition of formaldehyde, thus including the acid excreted as ammonium (Jørgensen, 1957).

AUGMENTED HISTAMINE TEST After an overnight fast a tube was introduced into the stomach through the nose and the position checked radiologically. Constant machine suction was started, frequently interrupted by manual aspiration. Following a period of one to one-anda-half hours, measuring the basal secretion, a maximal acid response to histamine was produced, infusing histamine acid phosphate intravenously at a rate of 0.04 mg. per kg. per hour. An antihistamine drug (mepyramine $20 \mathrm{mg}$.) was added to the solution of histamine. The infusion lasted for one hour, but aspiration was continued for another one-and-a-half hours. The aspirated gastric juice was collected at 15 -minute periods and the amount of hydrogen ions determined by titration with $\mathrm{N} / 10 \mathrm{NaOH}$ to a $\mathrm{pH}$ of $7 \cdot 4$.

TEST MEAL To produce a 'maximal' physiological stimulation of the gastric acid secretion, an appetizing meal was served, composed of beefsteak, sauce, potatoes and other vegetables, and a glass of water. The subject was told to eat as much as he liked.

THE SUBJECTS The diagnoses of cases 1-8 are listed in Tables 1 and 11 ; case 9 was a patient with achlorhydria without any other demonstrable pathological condition of the gastro-intestinal tract.

\section{EXPERIMENTAL PROCEDURE AND CALCULATIONS}

CASES 1-4 The one-hour base excess volume of distribution was determined individually in these four individuals by following the base excess (BE) in the blood during aspiration of maximal histamine-stimulated gastric acid secretion. The net acid loss was estimated by adding the amount of acid (positive or negative) excreted in the urine in the one-hour period of histamine infusion to the amount of acid aspirated. Measuring the rise in the base excess concentration in the blood, the one-hour volume of distribution can be calculated as:

$\mathrm{f}_{(60)} \times$ body weight $(\mathrm{kg})=$. net acid loss $\left(\mathrm{mEq} . \mathrm{H}^{+}\right) / \triangle \mathrm{BE}$ (mEq./1 blood)

The subscript 60 on the coefficient of distribution refers to the time dependance of the volume of distribution. The four individual coefficients are shown in Table I, the mean value being 0.29 with an S.D. of 0.02 . This base excess distribution is identical with that measured in nine investigations reported in a previous paper (Rune, 1965) using the same technique as described here. In Fig. 1 are shown the base excess values measured during aspiration of gastric juice in cases 1 and 2. The net acid loss is shown on the same figure. The relation between the base excess scale (left ordinate) and the acid loss scale (right ordinate) is the result of applying the calculated volume of base excess distribution to the net acid loss (base accumulation). The zero point on the acid loss scale is placed on the same ordinate value as the base excess value at the time when histamine infusion starts. For example, in case 1

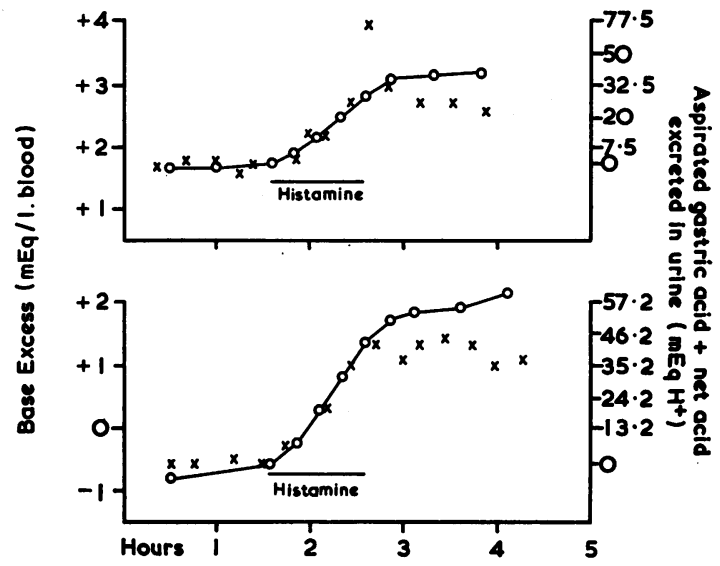

FIG. 1. Case 1: $\triangle$ base excess $/ \mathrm{hr} .=+1 \cdot 1 \mathrm{mEq} . / \mathrm{l} . / \mathrm{hr}$. (Value when histamine infusion starts: $+1 \cdot 7$, value 60 minutes later: + 2.8.) Net acid loss: $28 \mathrm{mEq} . \mathrm{H}^{+} / \mathrm{hr}$. Case 2: $\triangle$ base excess/hr. $=+1.9 \mathrm{mEq} . / \mathrm{l} . / \mathrm{hr}$. (Value when histamine infusion starts: -0.6 , value 60 minutes later: + 1.3.) Net acid loss: $42 \mathrm{mEq} . \mathrm{H}^{+} / \mathrm{hr}$.

$\times=$ Base excess during aspiration of gastric juice.

$\mathrm{O}-\mathrm{O}=$ Aspirated gastric acid + net acid excreted in urine.

(Fig. 1), the base excess value when infusion starts is $+1.7 \mathrm{mEq} . / 1$. blood, the value 60 minutes later when infusion is stopped is $+2.8 \mathrm{mEq} . / 1$. blood, which is the result of interpolation between the value measured six minutes before and that measured 14 minutes after the end of infusion, resp. $+2 \cdot 7$ and $+3 \cdot 0$. Thus the rise in base excess concentration in the blood in this 60 -minute period is $+1.1 \mathrm{mEq} . / \mathrm{l}$. blood. In the same period a net acid loss of $28 \mathrm{mEq} . \mathrm{H}^{+}$has been measured. Using the equation shown above, the base excess distribution in this individual with a body weight of $84 \mathrm{~kg}$. is calculated to be $25 \mathrm{l}$. Hence an acid loss of $25 \mathrm{meq} . \mathrm{H}^{+}$will correspond to a rise in base excess of $+1.0 \mathrm{mEq}$. $/ 1$. blood. It can be seen on the figure that base excess is decreased after the end of the histamine infusion. This is due to the expansion of the volume of base excess distribution, which as time goes by, will increase and deviate more and more from $0.30 \times$ body weight.

A few days later the test meal was given to the subject, the blood and urine being analysed as described. Using the measured one-hour volume of distribution, the rate of base accumulation in the body during the first hour of food-stimulated gastric acid secretion was calculated.

CASES 5-8 The test meal was given to the subjects on two different days. On both days the blood and urine were analysed as described. On the second day histamine acid phosphate was injected subcutaneously in a dose of $0.04 \mathrm{mg}$. per $\mathrm{kg}$. body weight 15 minutes after ingestion of food (except in case 6 where the interval was 50 minutes). An antihistamine (mepyramine $100 \mathrm{mg}$.) was injected intramuscularly half an hour previously. The one-hour base excess volume of distribution was estimated 
applying 0.30 as coefficient of distribution to this group. An augmented histamine test was performed on another day.

CASE 9 This subject had shown achlorhydria at several augmented histamine tests. The base excess was followed in the blood for four hours after the test meal was given.

\section{RESULTS}

CASES 1-4 The rate of base excess increase in the blood was found to be the same during aspiration of maximal histamine-stimulated gastric juice as after the test meal (Table I). The greatest difference was $15 \%$. On average the rate of base accumulation in the body (equivalent to the acid loss) was $28.6 \mathrm{mEq}$./ hr., as compared with a mean rate of acid secretion during the augmented histamine stimulation of $29 \cdot 2 \mathrm{mEq} . \mathrm{H}^{+} / \mathrm{hr}$.

On Fig. 2 the base excess values after the test meal are shown for cases 1 and 2 . In the same diagram are plotted the values during the augmented histamine test. For comparison the value for base excess at the time when the gastric secretion begins are brought to correspondence.

CASES 5-8 As seen in Table II the procedure applied to this group showed that the base excess increase in the blood in the first hour after ingestion of the test meal is not affected by injection of a dose of histamine accepted to produce a maximal stimulation of the gastric acid secretion, i.e., the rate of gastric acid secretion cannot be increased by a superimposed histamine stimulation. The difference between the rate of acid excretion in the urine during the two investigations was without quantitative importance.

Using an estimated one-hour volume of base excess distribution corresponding to $0.30 \times$ body weight in this group, a mean rate of gastric acid

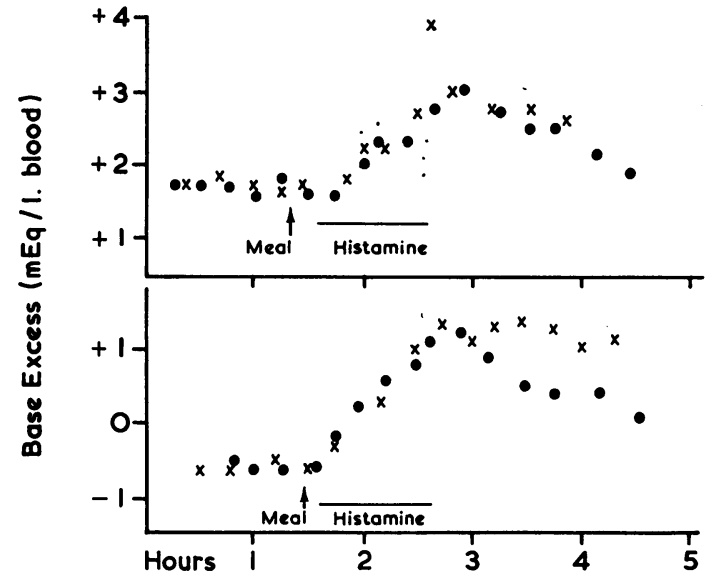

FIG. 2. Case 1: $\triangle$ base excess/hr. after meal $=\times 1 \cdot 3$ mEq./l./hr. (Value when inclination begins: $+1 \cdot 6$, value 60 minutes later: $+2 \cdot 9$.)

Case 2: $\triangle$ base excess/hr. after meal $=+1.7 \mathrm{mEq} / \mathrm{l} . / \mathrm{hr}$. (Value when inclination begins: $-0 \cdot 6$, value 60 minutes later: $+1 \cdot 1$.)

- Base excess after meal.

$\times$ Base excess during aspiration of gastric juice.

secretion (base accumulation) after the meal of $26 \mathrm{mEq}$. $/ \mathrm{hr}$. was calculated, compared with 28 $\mathrm{mEq} . \mathrm{H}^{+} / \mathrm{hr}$. during the augmented histamine test. The results can be read in Table II. In Fig. 3 the values from base excess from cases 5 and 6 can be followed. The results from the two investigations on each subject are plotted on the same diagram, after the level of the pre-prandial base excess values were brought into correspondence.

CASE 9 No significant change in the base excess concentration in the blood was observed after the meal in this subject, who had a diagnosis of achlorhydria (Fig. 4).
TABLE I

\begin{tabular}{|c|c|c|c|c|c|c|c|}
\hline Case & Diagnosis & $\begin{array}{l}\text { Weight } \\
\text { (kg.) }\end{array}$ & $\begin{array}{l}\text { Aspirated Acid } \\
\text { during One Hour of } \\
\text { Maximal } \\
\text { Histamine } \\
\text { Stimulation } \\
\left(m E q . H^{+} / h r .\right)\end{array}$ & $\begin{array}{l}\Delta \text { Base Excess/hr. during } \\
\text { Aspiration } \\
\text { (mEq./l. blood })\end{array}$ & Calculated & $\begin{array}{l}\text { DBase Excess/hr. after } \\
\text { Meal } \\
\text { (mEq./l. blood })\end{array}$ & $\begin{array}{l}\text { Calculated Gastric } \\
\text { Acid Secretion } \\
\text { after Meal } \\
\left(\mathrm{mEq} . \mathrm{H}^{+} / \mathrm{hr} .\right)\end{array}$ \\
\hline 1 & $\begin{array}{l}\text { Inguinal } \\
\text { hernia }\end{array}$ & 84 & 28 & $+1 \cdot 1$ & 0.30 & $+1 \cdot 3$ & 33 \\
\hline 2 & $\begin{array}{l}\text { Duodenal } \\
\text { ulcer }\end{array}$ & 71 & 42 & +1.9 & 0.31 & $+1 \cdot 7$ & 38 \\
\hline 3 & $\begin{array}{l}\text { Duodenal } \\
\text { ulcer }\end{array}$ & 44 & 24 & $+2 \cdot 0$ & 0.28 & $+1 \cdot 7$ & 21 \\
\hline 4 & Dyspepsia & 76 & 23 & $+1 \cdot 1$ & $0 \cdot 27$ & $+1 \cdot 1$ & 23 \\
\hline
\end{tabular}




\section{TABLE II}

$\begin{array}{cll}\text { Case Diagnosis } & \begin{array}{l}\text { Weight } \\ \text { (kg.) }\end{array} & \begin{array}{l}\Delta \text { Base Excess/hr. } \\ \text { after Meal on } \\ \text { First Day } \\ \text { (mEq.ll. blood) }\end{array} \\ & \end{array}$

$\triangle$ Base Excess/hr, after Meal + Histamine Second Day (mEq./l. blood)

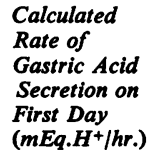

Calculated Rate of Gastric Acid Secretion on Second Day $\left(m E q . H^{+} / h r\right.$.
Gastric Acid Secretion during Augmented Histamine Test $\left(m E q . H^{+} / h r.\right)$

\begin{tabular}{llllllll}
\hline 5 & $\begin{array}{l}\text { Duodenal } \\
\text { ulcer }\end{array}$ & 81 & +1.9 & +1.8 & 45 & 43 & 40 \\
6 & $\begin{array}{l}\text { Duodenal } \\
\text { ulcer }\end{array}$ & 65 & +0.9 & +1.0 & 17 & 19 & 23 \\
7 & $\begin{array}{l}\text { Gastric } \\
\text { ulcer }\end{array}$ & 59 & +1.3 & +1.4 & 22 & 24 & 22 \\
8 & Gastritis & 58 & +1.1 & +1.0 & 18 & 17 & 28
\end{tabular}
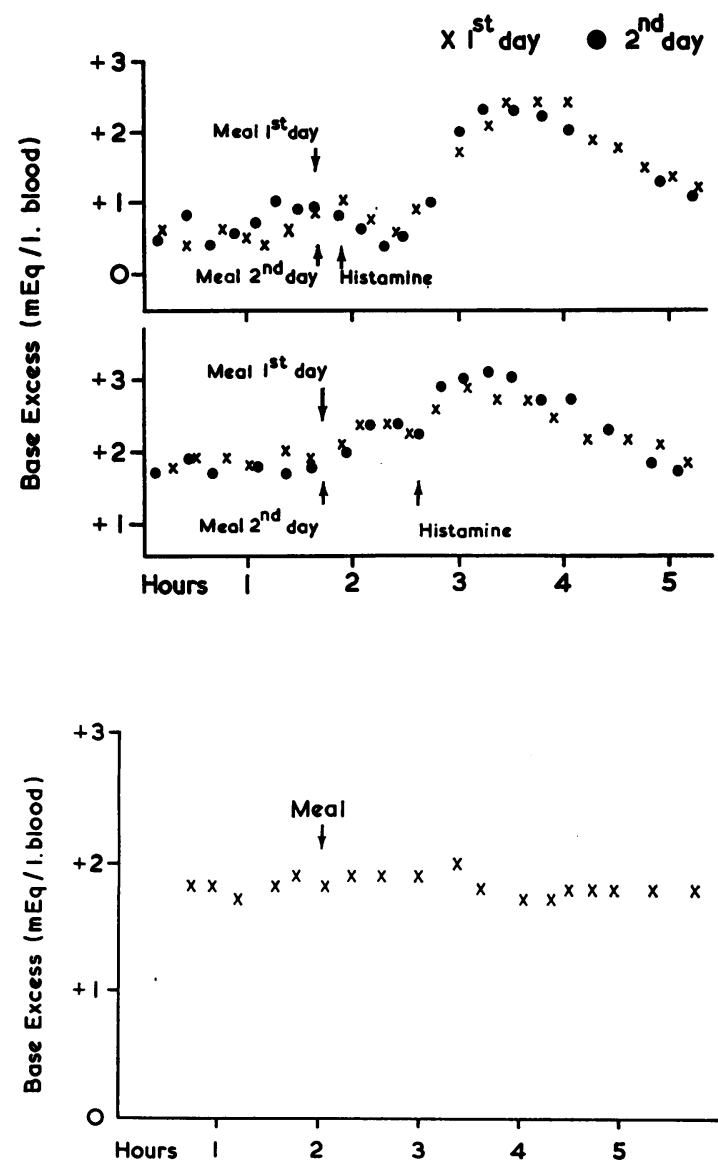

FIG. 3. Case 5: $\triangle$ base excess/hr. after meal first day $=$ $+1.9 \mathrm{mEq} . / \mathrm{l} . / \mathrm{hr} .(+2.4-(+0.5))$; base excess/hr. after meal second day $=+1 \cdot 8 \mathrm{mEq} . / \mathrm{l} . / \mathrm{hr} .(+2 \cdot 3-(+0 \cdot 5)$. $)$ Case 6: $\triangle$ base excess/hr. after meal first day $=+0.9$ $m E q . / l . / h r .(+2 \cdot 8-(+1.9)) ; \triangle$ base excess/hr. after meal second day $=+1.0 \mathrm{mEq} . / \mathrm{l} . / \mathrm{hr} .(+2.9-(+1.9)$. $)$ Case 9: $\triangle$ base excess/hr. after meal $=0.0 \mathrm{mEq} . / \mathrm{l} . / \mathrm{hr}$.
DISCUSSION

VALUE OF THE METHOD The rise in base concentration in the blood during digestion has been observed by others (Dodds and McIntosh, 1923; Cullen and Earle, 1929; Hanke, Johannesen, and Hanke, 1931; Shock and Hastings, 1934; Hastings and Eisele, 1940; Denolin, 1942; De Langen, 1956; Monsaingeon, Bernier, and Tauret, 1960) but not used for evaluation of the rate of gastric acid secretion.

This application is possible, provided that (1) the gastric acid secretion is followed by an equivalent acid deficit in the body. (2) The distribution in the body of the acid deficit can be measured. (3) The increase in acid deficit (base excess) in the blood can be measured with a reasonable accuracy compared with the alteration induced by the gastric secretion. (4) No quantitatively important production or secretion of non-volatile acid or base takes place in the body other than the secretion of acid in the stomach.

The secretion of hydrochloric acid from the parietal cells is the result of a metabolic process in the cell, leading to a concentration of hydrogen ions supplied by the blood. Therefore an equivalent acid deficit (base accumulation) will develop in the surrounding milieu, whether this is the rest of the body or the nutrient solution of the gastric mucosa during an experiment in vitro. Davies (1948 and 1951) and Teorell (1951) have measured this equivalence.

The initial volume of a base excess distribution has been measured by infusing hypertonic bicarbonate solution in man by Singer, Clark, Barker, Crosley, and Elkinton (1955). They found the volume to correspond to $21 \%$ of the body weight. The half time of this initial distribution was about five minutes. The coefficient of distribution 30 minutes after the bicarbonate infusion was found to be 0.31 , and the same result is reported by Mellemgaard and Astrup (1960) using a similar technique. 
The half time of this distribution is three to four hours (Singer et al., 1955).

The author has in a previous paper (Rune, 1965) shown that the rate of base accumulation in the body during an augmented histamine test was identical to the simultaneous rate of acid secretion, using $0.30 \times$ body weight as volume of base excess distribution. The S.D. of the estimated acid loss as compared with that measured by aspiration was $6 \mathrm{mEq} . \mathrm{H}^{+}$. In the present work (cases 1-4) the corresponding S.D. was $2 \mathrm{mEq} . \mathrm{H}^{+} / \mathrm{hr}$. The improvement is mostly due to a higher accuracy in determining base excess in the blood (previously S.D. $0 \cdot 2 \mathrm{mEq}$./1. blood, in the present work $0.1 \mathrm{mEq}$./1. blood).

The accuracy of the method employed for determining the base excess concentration in the blood is illustrated by the small deviations from the mean value occurring in the periods before stimulation was introduced (Figs. 1-3) and during the whole five-hour period measuring the base excess in the blood of the subject with achlorhydria (Fig. 4). The mean S.D. of the determination is $0.1 \mathrm{mEq}$./1. blood. This accuracy is acceptable, considering that the change in base excess per hour, on which the calculation of the rate of acid secretion is based, varied from 0.9 to $2.0 \mathrm{mEq}$./1. blood.

Accumulation in the body of non-volatile acid or base compounds may be the result of metabolic processes. Food ingredients (protein) containing sulphur and phosphorus lead to formation of protein-donors in amounts ranging from 20 to 80 mEq./24 hours, dependent on the protein intake (Hunt, 1956; Relman, Lennon, and Lemarr, 1961). This rate of acid formation is hence insignificant compared with the rate of gastric acid secretion.

Excretion in the urine of acid or base may be of quantitative importance, but measurement of the excretion makes correction possible.

Concerning acid or base loss from other parts of the gastrointestinal tract, it is evident that the pancreatic secretion of bicarbonate is the main problem. In a recent paper, Preshaw and Grossman (1965) reported from experiments on dogs that the maximal rate of bicarbonate secretion from the pancreas during stimulation with exogenous secretin (300-600 units $/ \mathrm{hr}$.) was $12 \mathrm{mEq}$. $/ \mathrm{hr}$. This was approximately one-third of the maximal rate of acid secretion by the stomach during exogenous stimulation with gastrin. It is thus a possibility that bicarbonate secreted from the pancreas in the early post-prandial period may be of quantitative importance compared with the gastric acid secretion. In the present study observation on the individual with achlorhydria showed no significant accumulation of bicarbonate after the test meal (Fig. 4). However, the stimulation of the pancreas in this case may be reduced, because of lack of stimulation caused by acid in the duodenum. Therefore no conclusion can be drawn from this observation concerning the relation in subjects with normal acid secretion from the stomach.

Passage of the gastric contents through the pylorus and reabsorption of acid within the first hour after the meal cannot be excluded, and has been accepted as an explanation for the few occasions on which a slow down was observed in the base excess increase during the first hour. But this sign of early reabsorption of a significant amount of acid is a rare finding when solid food with a high buffer capacity is used as the test meal.

To summarize, the rate of base accumulation in the body during the first hour of stimulated gastric acid secretion can be measured with satisfying accuracy, and it will be equivalent to the acid secretion, unless accumulation of pancreatic bicarbonate secretion or reabsorption of the gastric acid occurs in the same one-hour period. In that case the rate of gastric acid secretion will be underestimated.

RESULTS Concerning the results obtained on the gastric acid secretion after a solid meal, the procedure employed in cases 1-4 makes direct comparison possible between the increase in base excess during the 60 minutes when gastric juice was aspirated, stimulated by a maximal histamine dose, and the increase during the equivalent period after the meal. The results shows that the rate of loss of nonvolatile net acid is approximately the same during the two modes of stimulation.

According to the discussion above, the foodstimulated secretion could be greater than the measured rate of acid loss, the disparity being roughly equivalent to the rate of intestinal accumulation of bicarbonate secreted from the pancreas in the first hour after the meal. No measurements have been published on this rate of pancreatic secretion after ingestion of solid food, but the author has often observed a significant drop in the base concentration in the blood immediately after taking milk. This can be explained only by an intense bicarbonate secretion. The reason why the solid meal does not cause a similar reaction is either that a time lag exists between the gastric and the pancreatic response, or that the rate of gastric acid secretion is far greater than the rate of bicarbonate secretion. This last possibility implies that the gastric acid response after the meal is higher than during the maximal histamine infusion. When the studies by Maklouf, McManus, and Card (1964) are considered such a relation cannot be excluded. They showed that in man the maximal acid response after injection of gastrin was some $10 \%$ greater than that found during histamine stimulation. These considerations 
have initiated experiments on dogs, where the pancreatic secretion of bicarbonate is measured during a procedure identical to that applied to cases 1-4 in this investigation, i.e., both during a protein-rich meal and during maximal stimulation by histamine. Preliminary results indicate that during the first hour after ingestion of solid food, the base equivalents secreted from the pancreas amount to $20 \%$ of the acid equivalents secreted in the stomach. Applied to the present study, this suggests that in man also the rate of gastric acid secretion is some $20 \%$ higher than estimated and thus exceeds the histamine-stimulated secretion. It should, however, be pointed out that the rate of acid secretion during a maximal histamine-infusion test does not reach its peak value in the first 15-30 minutes after the beginning of the infusion. Therefore the acid output during the first hour of a maximal histamine stimulation will be smaller than the maximal secretory capacity per hour. This difference amounts to $15-25 \%$. Furthermore, a small percentage of the acid secreted during the histamine test may have escaped aspiration.

These arguments lead to the conclusion that the results obtained from cases 1-4 shows a good agreement between the rate of acid secretion during stimulation by food and the maximal rate during histamine stimulation.

The investigations of cases $5-8$, in which a maximal dose of histamine was superimposed on the test meal, showed that when what can be supposed to be a maximal food stimulus is applied, no further gastric acid response can be produced by histamine. This result is in contrast to a report by Hunt (1956). He used a liquid meal (pectin) and found that injection of histamine could increase the amount of acid aspirated 30 minutes after the meal. The most likely explanation for the divergence is that the pectin meal is a weaker stimulant of the acid secretion than is a beefsteak. The results obtained from the procedure employed in cases 5-8 thus strongly support the conclusion drawn from the results in cases 1-4 that the rate of gastric acid secretion stimulated by food is approximately the same as that stimulated maximally by histamine.

\section{CONCLUSIONS}

This study showed that a maximal stimulation of the gastric parietal cells with histamine, as applied during the augmented histamine test, can by no means be considered an unphysiological stress of the acid-secreting mechanism, since a normal meal provokes an acid secretion with an intensity at least as high as that found during a maximal histamine stimulation. From this it follows that when a measurement is desired of the daily secretory activity in the stomach, a gastric function test based on a less potent stimulation of the parietal cells than that provoked by a maximal dose of histamine $(0.04 \mathrm{mg}$. histamine acid phosphate per $\mathrm{kg}$. body weight) cannot be recommended.

\section{SUMMARY}

The method for estimating the rate of gastric acid secretion without aspiration of the stomach contents (Rune, 1965) has been applied to the gastric secretion during digestion of solid food.

In eight individuals the estimated rate of gastric secretion of hydrochloric acid after a test meal, composed of beefsteak and vegetables, averaged $27 \cdot 3$ $\mathrm{mEq} . / \mathrm{hr}$., and the secretion during the augmented histamine test $28.6 \mathrm{mEq}$. $/ \mathrm{hr}$.

It is emphasized that since the pancreatic secretion of bicarbonate is not accounted for by the calculation, the possibility exists of a higher acid response to stimulation by food than following a maximal stimulation by histamine.

I am indebted to Mrs. E. Mechlenburg, Mrs. B. Petersen, Miss K. Teglkamp, and Miss L. Knutsson for their valuable laboratory assistance.

\section{REFERENCES}

Astrup, P., Jørgensen, K., Siggaard-Andersen, O., and Engel, K. (1960). The acid-base metabolism. A new approach. Lancet, 1, 1035-1039.

Cullen, G. E., and Earle, J. P. (1929). Studies of the acid-base condition of blood. J. biol. Chem., 83, 545-559.

Davies, R. E. (1948). Hydrochloric acid production by isolated gastric mucosa. Biochem. J., 42, 609-621.

, (1951). The mechanism of hydrochloric acid production by the stomach. Biol. Rev., 26, 87-113.

Denolin, H. (1942). La Vague alcaline post prandiale. Rev. belge Sci. méd., 14, 288-323.

Dodds, E. C., and McIntosh, J. (1923). Variations in the $\mathrm{CO}_{2}$ content of the blood constituents in relation to meals. J. Physiol. (Lond.), 57, 139-142.

Hanke, M. E., Johannesen, R. E., and Hanke, M. M. (1931). Alkalinity of gastric venous blood during gastric secretion. Proc. Soc. exp. Biol. (N.Y.), 28, 698-700.

Hastings, A. B., and Eisele, C. W. (1940). Diurnal variations in the acid-base balance. Ibid., 43, 308-312.

Hunt, J. N. (1956). The influence of dietary sulphur on the urinary output of acid in man. Clin. Sci., 15, 119-134.

Jørgensen, K. (1957). Titrimetric determination of the net excretion of acid/base in urine. Scand. J. clin. Lab. Invest., 9, 287-291.

Kay, A. W. (1953). Effect of large doses of histamine on gastric secretion of $\mathrm{HCl}$. An augmented histamine-test. Brit. med. J., 2, 77-80.

Langen, C. D. de (1956). De zuur-basehuishouding bij de agastricus. Ned. T. Geneesk., 100, 246-247.

Makhlouf, G. M., McManus, J. P. A., and Card, W. I. (1964). The action of gastrin II on gastric-acid secretion in man. Comparison of the 'maximal' secretory response to gastrin II and histamine. Lancet, $2,485-490$.

Mellemgaard, K., and Astrup, P. (1960). The quantitative determination of surplus amounts of acid or base in the human body. Scand. J. clin. Lab. Invest., 12, 187-199.

Monsaingeon, A., Bernier, J. J., and Tauret, P. (1960). Les pertes de liquide gastrique. Path. et biol., 8, 1351-1357. 
Preshaw, R. M., and Grossman, M. I. (1965). Stimulation of pancreatic secretion by extracts of the pyloric gland area of the stomach. Gastroenterology, 48, 36-44.

Relman, A. S., Lennon, E. J., and Lemann, J., Jr. (1961). Endogenous production of fixed acid and the measurement of the net balance of acid in normal subjects. $J$. clin. Invest., 40, 16211630.

Rune, S. J. (1965). The metabolic alkalosis following aspiration of gastric acid secretion. Scand. J. clin. Lab. Invest., 17, 305-310.
Shock, N. W., and Hastings, A. B. (1934). Studies of the acid-base balance of the blood. III. Variation in the acid-base balance of the blood in normal individuals. J. biol. Chem, 104, 585-600.

Singer, R. B., Clark, J. K., Barker, E. S., Crosley, A. P., Jr., and Elkinton, J. R. (1955). The acute effects in man of rapid intravenous infusion of hypertonic sodium bicarbonate solution. I. Changes in acid-base balance and distribution of the excess buffer base. Medicine (Baltimore), 34, 51-95.

Teorell, T. (1951). The acid-base balance of the secreting isolated gastric mucosa. J. Physiol. (Lond.), 114, 267-276. 